\title{
PENDIDIKAN ISLAM DI MINORITAS MUSLIM (Suatu Tinjauan Kultur pada Pondok Pesantren Assalam Kota Manado)
}

\author{
Saddam Husein, M.Pd.I \\ PAI FITK IAIN Ambon \\ Email: saddam@iainambon.ac.id
}

\begin{abstract}
This article describes the culture of the Assalam Islamic Boarding School in Manado, which exists to this day, while standing in the center of a Muslim-majority area. Islamic boarding schools Islamic boarding schools do not cause problems for non-Muslim communities in boarding schools. This study found that non-Muslim communities around the pesantren were very good and harmonious. This paper discusses two important things, first, about the needs and challenges of the Assalam Islamic Boarding School in Manado to continue to exist amid its interests in the area of Muslim freedom. Second, Culture and Success in developing Islamic Education among Muslims.
\end{abstract}

Keyword: Muslim minority, Pondok Pesantren Assalam, Manado City

\begin{abstract}
Abstrack Artikel ini menjelaskan mengenai kultur Pondok Pesantren Assalam Kota Manado yang eksis sampai sekarang ini, walaupun berdiri tegak di tengah wilayah minoritas muslim. Realitasnyamenjelaskan bahwa eksistensi Pondok pesantren tersebut tidak menjadi masalah bagi masayarakat non muslim yang berada di sekitar pesantren. Studi ini menemukan bahwa relasi masyarakat non muslim sekitar pesantren sangat baik dan harmonis. Tulisan ini menegaskan dua hal penting, pertama, tentang kebutuhan dan tantangan Pondok Pesantren Assalam Kota Manado untuk tetap eksis ditengah keberadaannya di wilayah minoritas muslim. Kedua, Kultur serta upaya dalam mengembangkan Pendidikan Islam di tengah minoritas muslim.
\end{abstract}

Kata kunci: Minoritas Muslim, Pondok Pesantren Assalam, Kota Manado

\section{Pendahuluan}

Minoritas kelompok, masyarakat, ataupun agama sering didentifikasi sebagai heterodoks, karena dianggap berbeda dengan norma-norma yang diyakini kebenarannya oleh kelompok mayoritas lain. Tentu tidak mudah 
menentukan sebuah penafsiran doktrin keagamaan sebagai 'benar' dan 'tidak benar', 'sah' atau 'tidak sah', mengingat masing-masing kelompok memiliki ukurannya sendiri dalam menentukan kebenaran itu. Akan tetapi, terlepas dari kerumitan itu, ketegangan antara mereka yang disebut sebagai kaum ortodoks dan heterodoks di satu sisi telah menghasilkan sebuah khazanah intelektual yang menggambarkan sejarah dan dinamika pemikiran keagamaan, di wilayah Nusantara khususnya, dan di dunia Islam pada umumnya (Oman Fathurrahman, 2011)

Manado yang berpenduduk mayoritas beragama Kristen, sedangkan Islam merupakan agama yang di anut ke 2 terbesar selain dari agamaagama lain yang ada di kota manado, keberagaman dan kemajemukan yang ada pada masyarakatnya membuat kota manado kaya akan budaya. Masyarakat menunjukkan hubungan mendalam antar budaya berbagai macam masyarakat yang terjadi sebagai akibat adaptasi kultural dengan nilai budaya local (Frangky Suleman,2007).

Selain menjadi pusat administrasi pemerintahan, Manado juga merupakan pintu masuk pertama dan salah satu pusat pengembangan Kristen ke pelosok Minahasa dan sekitarnya (Basri Amin, 2005). Sehingga tidak heran jika mayoritas penduduk di kota ini adalah penganut agama Kristen, yang terus mengalami perkembangan dan perbaikan baik dari segi ritual maupun sarana dan prasarana yang menunjang kegiatan keagamaannya. Sementara umat Islam tergolong minoritas dengan pemahaman agama yang saat itu masih minim karena kurangnya pendidikan dan pengajaran Islam secara intens dan terus- menerus (Jurnal Ilmu Sosial dan Budaya).

Seiring dengan berjalannya waktu, umat Islam khususnya di kota Manado mengalami peningkatan secara kualitas maupun kuantitas. Jumlah pemeluk agama Islam semakin meningkat, hal ini dapat dikatakan sebagai wujud kontribusi sejak didirikannya sebuah lembaga pendidikan Islam dengan model pesantren, yang ketika itu diberi nama Pondok Pesantren Putri Assalam Manado pada tahun 1989. Pesantren Putri As 
Salam Manado berdiri atas inisiatif dan ide para tokoh pegawai pajak muslim Manado yang menggalang dana zakat, infaq dan sedekah (ZIS) untuk mengembangkan kepedulian terhadap masyarakat muslim Manado. Baik dalam memenuhi permohonan bantuan secara pribadi maupun kelompok untuk kepentingan pembangunan sarana ibadah, sosial, pendidikan dan lain sebagainya (Profil As-Salam Manado).

Meski pada awalnya inisiatif pendirian ponpes Assalam Manado sebagai wadah gerakan sosial dan kepedulian atas eksistensi umat Islam saat itu, namun kini telah menuai hasil yang sangat signifikan. Setelah membangun masjid, ponpes Assalam Manado melalui yayasan membangun panti asuhan yatim piyatu, dan lama kelamaan secara bertahap membangun gedung madrasah yang diproyeksikan sebagai tempat belajar formal bagi anak-anak yaitm piatu tersebut.

Hal yang unik dan menarik simpati penulis untuk menelusuri dari sepanjang deretan sejarah ponpes Assalam manado adalah keberadaannya ditengah wilayah minoritas muslim. Sehingga titik fokus dalam artikel ini adalah tentang kebutuhan dan tantang Ponpes Assalam Manado di wilayah minoritas muslim serta kultur dan upaya dalam pengembangan pendidikan Islam.

\section{METODE}

Penelitian ini menggunakan pendekatan Deskriptif Kulitatif secara komprehensif melalui studi fenomenologi yang mempelajari aktifitas yang berlangsung di pondok pesantren Assalam Putri Kota Manado. Konsep pada penelitian ini sepenuhnya menggunakan prinsip-prinsip kualitatif (Ponterotto, J. G,2006) Kriteria gounded theory menjadi prosedur dalam penelitian ini.

\section{HASIL}

Realitas pendidikan yang berlangsung di Pondok Pesantren Assalam Kota Manado mengandung nilai-nilai multikultural yang 
menjungjung-tinggi arti nilai perbedaan serta mengimplementasikannya kedalam prilaku menghargai, tenggang rasa, toleransi, tolong-menolong, gotong-royong serta kegiatan sosial lainnya. Sikap dewasa serta watak yang mampu merespon serta menerima perbedaan sosial, budaya, etnis dan bahkan perbedaan keyakinan sekaligus merupakan bentuk watak dan pemahaman berwawasan multikultural yang mumpuni dalam menjalin hidup bersama dalam lingkar perbedaan.

Pada awalnya, Pondok Pesantren As Salam Manado bernama Pesantren Putri As Salam Manado, yang khusus menerima santri putri. Didirikan oleh Yayasan Karya Islamiyah Manado pada tahun 1989.

Pesantren Putri As Salam Manado berdiri atas inisiatif dan ide para tokoh pegawai pajak muslim Manado yang menggalang dana zakat, infaq dan sedekah (ZIS) untuk mengembangkan kepedulian terhadap masyarakat muslim Manado. Baik dalam memenuhi permohonan bantuan secara pribadi maupun kelompok untuk kepentingan pembangunan sarana ibadah, sosial, pendidikan dan lain sebagainya.

Mulanya, gerakan sosial ini dimotori oleh panitia pembangunan yang dipimpin Bapak Drs. Soemijanto. Ketika dana sudah terkumpul, maka pembebasan tanah dan pembangunan sarana pun dimulai. Pada tahun 1988 dibangunlah masjid sebagai sarana ibadah, diberi nama Masjid As Salam yang berlokasi di perumahan pajak Wale Temboan di Jln. 17 Agustus Manado.

Berhasil membangun masjid, Yayasan kemudian mendirikan Panti Asuhan Yatim Piatu As Salam untuk menampung anak yatim-piatu dan anak dari orang tua tidak mampu. Berlokasi di Bailang, Kec. Bunaken Kota Manado. Peletakan batu pertama dilaksanakan pada 6 Mei 1986 oleh Wakil Gubernur KDH tingkat I Sulawesi Utara; Drs. Hi. Abdullah Mokoginta. Diresmikan pada 9 Nopember 1988 oleh Gubernur Kepala Daerah Tingkat I Sulawesi Utara; C. J. Rantung (Profil Assalam Manado).

Masih di lokasi yang sama, tanggal 7 Desember 1988 Yayasan membangun gedung madrasah yang diproyeksikan sebagai tempat 
belajar formal bagi anak-anak yaitm piatu tersebut. Pada perkembangan selanjutnya, gedung madrasah itu menjadi cikal bakal berdirinya Pesantren Putri As Salam Manado. Pembangunan dua sarana pendidikan itu diketuai oleh Drs. Soemijanto, yang waktu itu menjabat sebagai Kepala Inspeksi Pajak Sulawesi Utara.

Dalam perkembangannya, pesantren putri tersebut maju pesat, sehingga dibangunlah asrama dua lantai untuk menampung santriwati, selain asrama panti asuhan. Bahkan pada tahun 1995, juga dibangun gedung belajar 3 lantai dan Masjid As Sami. Gedung belajar tersebut diresmikan oleh Drs. H. Ahmad Din pada tanggal, sedangkan masjid As Sami peresmiannya ditandatangani oleh Drs. Saiful Hamid, MA., masingmasing sebagai tokoh pendiri As Salam. Kedua bangunan tersebut ditandatangani peresmiannya pada tanggal 12 Agustus 2013. Hingga kini, pondok pesanren Assalam Kota Manado terus mengalami kemajuankemajuan serta semakin dipercaya oleh masyarakat sebagai salahsatu lembaga pendidikan dengan basis pesantren.

\section{PEMBAHASAN}

Berdasarkan hasil pengamatan peneliti, Penyelenggaraan pendidikan Islam di Pondok pesantren Assalam Manado tempak sangatlah harmonis, hal demikian tergambarkan oleh aktifitas antara santri, ustad maupun para kiyai yang ada di lingkup pesantren. Walaupun secara letak geografis, sosio kultural dan faktor lainnya yang menunjukan letak pondok pesantren Assalam Manado berada di tengah-tengah mayoritas non-Muslim, tetapi kondisi tersebut tidaklah menjadi hambatan, kendala, maupun sesuatu yang menghalangi mereka untuk tetap menjalankan proses penyelenggaraan pendidikan Islam dalam kegiatan pembelajaran. Tidak sampai disitu saja, relasi sosial antara santri, Ustad dan Kiyai di Pondok Pesantren Assalam Kota Manado dengan Masyarakat sekitar sangatlah harmonis, baik yang seiman maupun dengan mereka yang berbeda keyakinan. Bahkan dalam urusan tertentu, 
yang kaitannya dengan sosial kemasyarakatan, mesyarakat sekitar dalam hal ini yang non muslim dan warga di lingkup pesantren Assalam Kota Manado seringkali melakukan kegiatan bakti sosial secara bersama, apakah itu soal membersihkan lingkungan, dalan lain sebagainya.

Keadaan geografis serta letaknya di kerumunan mayoritas non Muslim justru menjadi media implementasi dari hasil belajar mereka di pesantren maupun sekolah formal. Dimana diajarkan tentang pentingnya saling menghormati, tolong menolong, menghargai dan memahami orang yang non muslim bila sedang melakukan ibadah. Sebab pada dasarnya dalam ajaran Islam menuntuk untuk tidak saja menjaga hubungan dengan tuhan, alam namun juga kepada sesame manusia.

Walaupun tidak dapat dipungkiri, tentunya Pondok pesantren assalam manado lebagai Lembaga Pendidikan Formal dan non Formal didalamnya juga sangat mengharapkan dan membutuhkan perhatian oleh pemerintah setempat demi tercapainya sarana dan prasarana, tenaga administrasi serta tenaga pendidik yang memadai, agar Pondok Pesantren Assalam Manado kedepan jauh lebih maju dan berkembang lagi.

Pondok Pesantren Assalam Kota Manado Ini tentunya memiliki ciri khas dan keunikan tersendiri jika dibandingkan dengan pondok pesantren lainnya, walaupun ada juga yang memiliki persamaan dari segi geografis dan realitas sosial dengan pondok pesantren lainnya. Keunikannya adalah, tidak jauh dari pesantren terdapat beberapa gereja, posisinya tepat disamping, ada juga dibelakang pesantren serta terdapat juga gereja yang tak jauh posisinya di depan pesantren. Namun yang patut diapresiasi adalah, kegiatan keagamaan, apakah itu soal ibadah, khalaqah, pengajian serta lainnya yang biasanya menggunakan pengeras suara tetap berjalan layaknya pesantren lainnya tanpa ada kendala, maupun protes dari masyarakat sekitar yang merasa terganggu, terutama mereka yang berbeda keyakinan. Bahkan menurut beberapa masyarakat sekitar yang kami temui, memberikan keterangannya bahwa adzan dikala subuh justru 
memberikan sumbangsih tersendiri bagi masyarakat non muslim yang ada disekitar pondok Pesantren Assalam Kota Manado, dimana mereka lebih mudah bangun lebih awal untuk melaksanakan aktifitasnya di pagi hari.

Penyelenggaraan pendidikan Islam di wilayah minoritas muslim tentunya menjadi tantangan tersendiri. hal yang menarik adalah, sebagian orang tua santri ada dari mereka yang beragama non muslim, namun tidaklah menjadi soal, sebab menurut mereka belajar tidak mesti dari mereka yang seiman saja, sebab siapapun bias menjadi guru selama itu menjadikan anak-anak mereka pribadi yang lebih baik serta memiliki masa depan yang cerah. keberadaan pondok Pesantren Assalam Manado ditengah lingkar mayoritas non Muslim justru menjadi spirit dan tonggak dakwah Islam tanpa saling bersinggungan dengan yang tidak seiman. Bila fakta, keunika dan realitas ini ditelusuri lebih dalam, maka sesungguhnya dapat ditarik benang merah bahwa masyarakat Manado sangat jauh dewasa dalam memahami realitas yang ada, dan sangatlah menerima bahwa perbedaan adalah sebuah keniscayaan, yang juga merupakan bagian dari ciptaan oleh sang maha pencipta perbedaan, yaitu Allah SWT.

Walaupun demikian, Pondok pesantren Assalam Manado bila dilihat dari sisi perkembangannya dari zaman ke zaman mengalami perkembangan dan kemajuan-kemajuan yang begitu signifikan. Bagaimana tidak, dari sisi penyelenggaraan pendidikan, Pondok Pesantren Assalam Manado menerapkan kurikulum kombinasi antara kurikulum dari kemendiknas dan kementeria Agama serta perpaduan oleh sentuhan ciri khas kepesantrenan. Sehingga inilah yang membuat pesantren tersebut begitu dewasa dalam menanggapi serta menyikapi berbagai persoalan yang tidak hanya berkaitan tentang pendidikan, namun juga tentang hubungan sosial kemasyarakatan serta hal-hal lainnya yang menuntut respon positif yang implementatif.

\section{KESIMPULAN}


a. Pondok Pesantren Assalam Kota Manado membutuhkan dukungan dari semua pihak, terutama pemerintah setempat, kiranya lebih responsif dan peduli terhadap kebutuhan-kebutuhan yang menunjang peningkatan kualitas mutu pendidikan. Tidak dapat dipungkiri sarana dan prasarana, serta ketersediaan guru/pengajar menjadi faktor terpenting dalam penyelenggaraan pembelajaran di pesantren Assalam Kota Manado. Walaupun pada faktanya, letak geografisnya menunjukan keberadaannya di lingkup minoritas muslim, namun tidaklah menjadi kendala dan penghalang yang menghambat dan mengganggu proses pembelajaran dan pembinaan di pesantren tersebut. Tantangan tersebut justru menjadi ujian dalam mengimplementasikan ilmu-ilmu yang diajarkan para guru, ustadz dan kiyai kepada para santri di Pondok Pesantren Assalam Kota Manado.

b. Dalam mewujudkan cita-cita pesantren yang ingin menjadikan para santrinya menjadi para insan kamil, yang tidak sekedar cerdas otak namun juga bersih dan mulia hatinya, maka pembelajaran dan pembinaan lebih ditekankan kepada pengimplementasian nilai-nilai kelslaman dalam kehidupan sehari-hari, yang dimulai dari diri sendiri para santri dan untuk sesame, serta terhadap masyarakat luas pada umumnya. Muatan mata pelajaran serta pembinaan yang berlangsung di Pondok Pesantren Assalam Kota Manado menunjukkan bahwa pembinaan yang diterapkan oleh para guru, ustadz maupun kiyai mengandung nilai-nilai yang menjunjung tinggi makna arti perbedaan dan menghargainya dalam bentuk saling memahami, toleransi serta menjadikan pesantren sebagai sumber kedamaian.

\section{DAFTAR REFERENSI}

[1] Ali Saifullah, Antara Filsafat dan Pendidikan (SurabayaIndonesia:Usaha Nasional, tt.) 
[2] Azra, Azyumardi. Nilai-Nilai Pluralisme dalam Islam Bandung: Nuansa, 2005

[3] A Idhoh Anas, H. "Kurikulum dan metodologi pembelajaran pesantren," Cendekia: Jurnal Kependidikan dan Kemasyarakatan, Volume 10.Nomor 01 (2012)

[4] A. Steenbrink, Karel. Pesantren Madrasah Sekolah, cetakan kedua, Jakarta: LP3ES, 1994.

[5] Abdullah, Hamid. Manusia Bugis Makassar, Jakarta: Inti Idayu Press, 1985.

[6] Abdurrahman Wahid, Menggerakan Tradisi Esai-esai pesantren, LKIS; Yogyakarta, 2001.

[7] Cobern, W. W., 1994. Constructivism and non-Western science education research. International Journal of Science Education

[8] Cobern, W. W., 1996. Worldview theory and conceptual change in science education. Science Education, 80(5)

[9] Dawam Rahardjo, M. "Dunia Pesantren dalam Peta Pembaharuan", dalam Pesantren dan Pembaharuan, cetakan kelima, Jakarta: LP3ES, 1995.

[10] Departemen Agama RI, Petunjuk Teknis Pondok Pesantren, Jakarta: 2004.

[11 Dhofier, Zamakhsyari. Tradisi Pesantren Studi tentang Pandangan Hidup Kyai, Jakarta: LP3ES, 1982.

[12] Dkk Uci Sabusi./lmu Pendidikan Islam, Yogyakarta; Deepublish, 2018.

[13] Fahmi, Muhammad. "Mengenal tipologi dan kehidupan pesantren," Syaikhuna, Jurnal pendidikan dan Pranata Islam, 6.2 (2015), 30119.

[14] Maleong, Lexy . Penelitian Kualitatif. Bandung: Rineka Cipta, 2001

[15] Dkk, Lanny Octavia. Kumpulan Bahan Ajar; Pendidikan Karakter Berbasis Tradisi Pesantren. Jakarta Selatan: Rumah Kitab, 2014.

[16] Moran, Dermot. Introduction to Phenomenology, London and New York: Routledge, 2000, 4. 
[17] Oman Fathurrahman, Sejarah Pengkafiran Dan Marginalisasi Paham Keagamaan Di Melayu Dan Jawa

[18] Zainal Abidin Ahmad, Memperkembang dan Mempertahankan Pendidikan Islam di Indonesia, cet.ke-1 (Jakarta:PT.Bulan Bintang, 1970 